\title{
An unexpected discovery of a new subgenus and a species of Plusiocampa (Campodeidae, Diplura) alongside an overview of Central European subterranean campodeids
}

\author{
Alberto SENDRA ${ }^{1, *} \&$ Dieter WEBER ${ }^{2}$ \\ ${ }^{1}$ Grupo de Investigación de Biología del Suelo y de los Ecosistemas Subterráneos, \\ Departamento de Ciencias de la Vida, Facultad de Biología, Ciencias Ambientales y Química, \\ Universidad de Alcalá, E-28871 - Alcalá de Henares, Madrid, Spain. \\ ${ }^{1}$ Servei de Patrimoni Històric, Ajuntament de Valencia, E-46008 - Valencia, Spain. \\ ${ }^{2}$ Evolutionary Biology \& Ecology, CP 160/12, Université libre de Bruxelles, \\ Avenue F.D. Roosevelt 50, B-1050 Brussels, Belgium. \\ ${ }^{2}$ Musée national d'Histoire naturelle, 25, rue Munster, L-2160 Luxembourg. \\ *Correspondig author: alberto.sendra@uv.es \\ ${ }^{2}$ Email: dieter.weber124@gmx.de \\ ${ }^{1}$ urn:1sid:zoobank.org:author:11636BAE-AE66-4898-A7C8-35B329E7E3A8 \\ ${ }^{2}$ urn:1sid:zoobank.org:author:5A75D195-AC69-4B70-8F9A-85E6259B3798
}

\begin{abstract}
An unexpected new subgenus and species of Campodeidae (Diplura), Plusiocampa (Pentachaetocampa) inopinata subgen. et sp. nov., a troglobitic species found in Schallsinger Höhle in an isolated karstic region in southwestern Germany is described. The new taxon shows two unique characters for the genus Plusiocampa: five dorsal femoral macrosetae and the presence of $g_{I}$-glandular setae in females. Two other Plusiocampa species have been studied and taxonomic remarks made for them; both are also cave dwelling species from Germany: Plusiocampa dobati Condé in Dobat, 1975 studied from eight caves in the Swabian Alb, and one unnamed species of Plusiocampa (Plusiocampa) from four caves in the Franconian Alb. The biogeographical and taxonomic affinities among Plusiocampa species of Central Europe are discussed. The distribution of Plusiocampa species in Central Europe runs alongside the frontier of the Pleistocene glaciations, with non-troglomorphic Plusiocampa species adjacent to the glacial limits and troglomorphic Plusiocampa species below. Worthy of note is the presence only in the northeast of the Central Alps of two relict Plusiocampinae species, the already known Hystrichocampa pelletieri Condé, 1948 and the new species $P$. (P.) inopinata subgen. et sp. nov.
\end{abstract}

Keywords. Germany, troglobite, Pentachaetocampa subgen. nov., glacial distribution.

Sendra A. \& Weber D. 2018. An unexpected discovery of a new subgenus and a species of Plusiocampa (Campodeidae, Diplura) alongside an overview of Central European subterranean campodeids. European Journal of Taxonomy 428: 1-21. https://doi.org/10.5852/ejt.2018.428 


\section{Introduction}

Cave-dwelling campodeid diplurans have been known from Central Europe since the end of the nineteenth century (Joseph 1882). Nowadays, about fifteen troglobitic species are known of. This subterranean fauna is well spread throughout the Dinaric Alps (Condé \& Bareth 1996) and on both sides of the Alps, in Austria (Condé 1954) and Switzerland (Condé 1962), including the northern karstic Italian regions (Bareth \& Condé 1984), and extending towards the northeast along the Inner Western Carpathian Mountains, in the north of Hungary (Stach 1929), and also within caves in the south of Slovakia (Lubomir Kováč pers. com.). In Germany only one troglobitic campodeid was found by Dobat (1975) in the Swabian Alb caves. Much later, samples from seven Swabian caves were used to properly describe (Condé 1993) the endemic species cited only by its name and a short description using a letter from Condé (Dobat 1975): Plusiocampa (s. str.) dobati Condé in Dobat, 1975.

Recently some accurate biospeleological studies have been made including sampling of cave-dwelling animals in North Rhine-Westphalia, Hesse, Rhenish-Palatinate, Saarland, Baden-Württemberg (mainly Swabian Alb), and Bavaria (mainly Franconian Alb), where more than 10.000 caves and artificial caverns are known, resulting in the discovery in a single cave (Schallsinger Höhle, Baden-Württemberg) of a new and remarkable subgenus (Figs 1-2) of the genus Plusiocampa, already well known from subterranean habitats in the Euro Mediterranean region. Furthermore, taxonomic remarks are added on the species $P$. dobati, known from several northern caves in Swabian Alb, and on the uncertain Plusiocampa (Plusiocampa) sp., which has been located in caves of the Franconian Alb, Bavaria.

\section{Material and methods}

\section{Sampling methods}

The new material of $P$. dobati was collected from eight caves in the Swabian Alb, Baden-Württemberg, Germany. In the Vetterhöhle, some specimens were caught by using an exhauster and were directly transferred to $96 \%$ ethanol. In addition, two ethan-diol-1,2-traps were used to collect further specimens. The collections from the traps were also transferred to $96 \%$ ethanol. In the Bärentalhöhle, P. dobati was collected by hand and directly transferred to $96 \%$ ethanol. Plusiocampa (Pentachaetocampa) inopinata subgen. et sp. nov. was collected in the Schallsinger Höhle, southern Black Forest, Baden-Württemberg, Germany. It was collected by using a wet paint brush and transferred directly to $96 \%$ ethanol. It was only found in the "Great Hall" between 195 and 230 m away from the entrance of the cave, where the cave is highly humid. Some specimens were found on organic material, others on the surface of a cave lake, several of them already dead.

\section{Material processing and identification}

The specimens were washed using distilled water and were put between slides and glass coverslips to be examined under a phase-contrast optical microscope (Leica DMLS) using Marc André II solution. The illustrations were made with a drawing tube, and the measurements were taken with an ocular micrometer. For measuring the length of the body, the specimens were mounted in toto and were measured from the base of the frontal process distal macrochaetae to the abdomen's supra-anal valve. For scanning electron microscopy (Hitachi S-4100), six specimens were coated with palladium-gold and used for scanning electronic microscopic photography and measurement of the sensilla.

The morphological descriptions and abbreviations used in this paper follow Condé (1956). We use gouge sensilla for the concavo-convexly shaped sensilla located on the antennae, described by Bareth \& Condé (1981) and whose function is still unknown. For the position of macrosetae we follow the terms of Condé (1956): $m a$, medial-anterior; la, lateral-anterior; lp, lateral-posterior; $m p$, medial-posterior and post, posterior. 


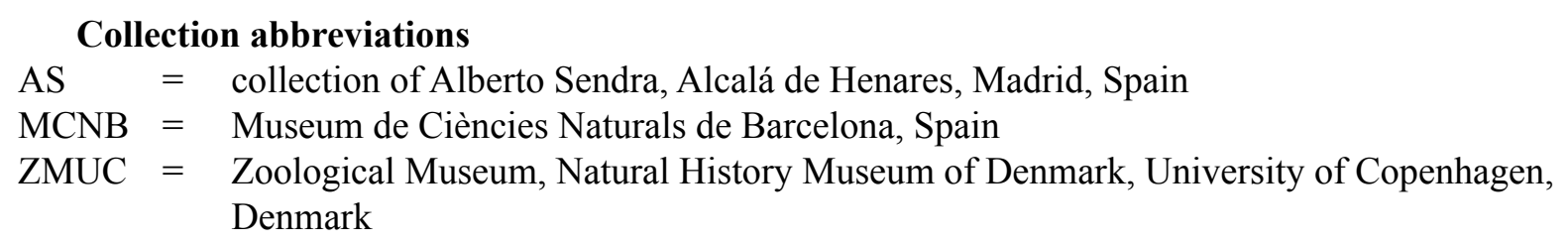

\title{
Results
}

\author{
Class Hexapoda Blainville, 1816 \\ Order Diplura Börner, 1904 \\ Suborder Rhabdura Cook, 1896 \\ Family Campodeiae Lubbock, 1873 \\ Subfamily Plusiocampinae Paclt, 1957 \\ Genus Plusiocampa Silvestri, 1912 \\ Pentachaetocampa subgen. nov. \\ urn:1sid:zoobank.org:act:40D4FFE0-74AE-4E70-A171-489291D8C85E
}

\section{Type species}

Plusiocampa (Pentachaetocampa) inopinata subgen. et sp. nov.

\section{Diagnosis}

Mesothoracic and metathoracic femur having five dorsal macrosetae (Fig. 12), up to 3 on prothoracic femur; presence of a narrow field of $g_{l}$-glandular setae in adult females (Figs $6,15-16$ ). In addition to these unique features, there are other characters in common with Plusiocampa species, such as: notal macrosetal formula $\left(1+1 \mathrm{ma}, 4+4 l a_{1,2,3,4}, 2+2 l p_{2,3}\right.$ pronotum, $1+1 \mathrm{ma}, 3+3 l a_{1,2,3}, 2+2 l p_{2,3}, 1+1 \mathrm{mp}$ mesonotum, and $1+1 \mathrm{ma}, 1+1 \mathrm{la}, 2+2 l_{2,3}, 1+1 \mathrm{mp}$ metanotum) (Fig. 3); $2-3$ ventral macrosetae on tibia (Fig. 12); slightly unequal elbow-like claws with short extension at the basal end of the posterior claw; lateral crests well developed (Figs 13-14); urotergal macrosetal formula (1+1 post ${ }_{1}$ on I-II; $1+1$ post $_{1}$, $1+1$ la on III; $2+2-3+3$ post $_{1,2,3}, 1+1$ la on IV; $5+5$ post $_{l-5}, 1+1$ la on V-VII, 6+6-5+5 post on VIII; 8+8 post on IX) (Fig. 4); urosternal macrosetal formula (7+7 on I; $5+5$ on II-VII; $2+2$ on VIII urosternites); female and male urosternite I with a narrow posterior field of $g_{l}$-glandular setae and subcylindrical appendages having a field of $a_{1}$-glandular setae (Figs 5-6).

\section{Etymology}

Penta in addition to chaetae (chaeta-), both from the Greek words which means five setae in reference to the noticeable five dorsal macrosetae on the femur.

\section{Phyletic affinities of the subgenera of Plusiocampa}

Recently, weak support was found for the classification of Campodeidae (Sendra et al. 2017), specifically within Plusiocampinae Paclt, 1957, based on the sparse number of solid characters and the high intraspecific and interspecific variation of many of them. This makes the taxonomy of the Plusiocampinae a delicate subject, with only a few synapomorphic features that can be used to put some order into the problematic subfamily proposed by Paclt (1957). All Plusiocampinae have at least 1+1 ma, $1+1 l a$ and $2+2 l p_{2,3}$ on its pronotum, known in all the ten previously described genera (Sendra et al. 2017). Among them, Plusiocampa with 57 species distributed around the Mediterranean Basin (Condé 1956) is the most diversified. The exceptions are the two Chinese species Plusiocampa (Dydimocampa) sinensis Silvestri, 1931 and Plusiocampa (Didymocampa) lipsae Condé, 1993, although both should be removed from Plusiocampa due to the macrosetal formula on urosternites II to VIII. Furthermore, 
a laminar telotarsal process is present in the case of $P$. lipsae. As a consequence, a new diagnosis of Plusiocampa is proposed: telotarsus with lateral crests and smooth-setiform lateral processes; pronotal formula with $1+1 m a$ and $2+2 l p$ macrosetae and from $2+2$ to $4+4 l a$ macrosetae; no less than 3+3 post macrosetae on urotergites VI-VII; no less than $5+5$ macrosetae on urosternites II-VII and $2+2$ macrosetae on urosternite VIII; and sensillum of antennomere III in a ventral position.

The genus Plusiocampa was divided into four subgenera based on two features, the dorsal macrosetae on the femur (Paclt 1957) and the ventral macrosetae on the tibia. Using these two synapomorphic features and additional ones, the following taxonomic key is proposed for the current five subgenera, Pentachaetocampa subgen. nov. included.

\section{Key of the subgenera of Plusiocampa}

1. No dorsal femoral macrosetae; without medial posterior notal macrosetae; extra macrosetae on the first to the eighth urosternites (with the exception of Plusiocampa (Stygiocampa) bureschi Silvestri, 1931 and Plusiocampa (Stygiocampa) denisi Condé, 1947) Stygiocampa Silvestri, 1934

- One, two or five dorsal femoral macrosetae; with or without medial posterior notal macrosetae. No extra macrosetae on the first to the eighth urosternites (with the exception of Plusiocampa (Plusiocampa) dargilani (Moniez, 1894))

2. One or two dorsal femoral macrosetae; with or without medial posterior notal macrosetae; without glandular setae $g_{1}$ in females

- Five dorsal femoral macrosetae; two to four ventral tibial macrosetae; with medial posterior notal macrosetae; with glandular setae $g_{l}$ in females Pentachaetocampa subgen. nov.

3. One dorsal femoral macroseta; zero to four ventral tibial macrosetae 4

- Two dorsal femoral macrosetae; two to four ventral tibial macrosetae ....Dydimocampa Paclt, 1957

4. One to four ventral tibial macrosetae; with or without medial posterior notal macrosetae; subequal to unequal claws but upmost the posterior claw is 2 times as longer as the anterior claw

Plusiocampa s. str. Silvestri, 1912

- No ventral tibial macrosetae; without medial posterior notal macrosetae; very unequal claws (posterior claw 2.5 times as long as anterior claw) Venetocampa Bareth \& Condé, 1984

For Plusiocampa s. str., its 47 species and 10 subspecies bear one dorsal femoral macroseta and 1-3 ventral tibial macrosetae. They are distributed from the Pontic Mountains in the northwest of the Anatolian Peninsula to the Betic Mountains on the Iberian Peninsula, colonizing the Balkan, Iberian and Italian peninsulas the Central French Massif included, and also the Aegean and most of the westMediterranean islands, reaching the Alps and the Carpathians Mountain ranges towards the north and in the south an isolated location in the Kabylie Mountains, northern Algeria. Most of its species inhabit subterranean ecosystems (Condé 1956) and only eight species and two subspecies can be considered soil-dwelling.

Stygiocampa has six species, all of them sharing the absence of dorsal femoral macrosetae in addition to a progressive reduction of the notal and urotergal macrosetae formula. Furthermore, four of these species have an increase in the number of macrosetae on the urosternites. All of this shows remarkable troglomorphic features, its species inhabiting the subterranean ecosystems around the Dinaric Alps (Condé \& Bareth 1996).

The two species of Dydimocampa share the possession of two dorsal femoral macrosetae and in both the $m p$ meso- and metanotal macrosetae are absent. They have been found at two unique locations, a 
cave in the Crimean Peninsula (Silvestri 1949) and in the Movile Cave (Condé 1996) in the southeast of Romania, both near the Black Sea.

Only one species is proposed in Venetocampa: Plusiocampa (Venetocampa) paolettii Bareth \& Condé, 1984, collected from a single cave in the Feltrine Alps. It is characterized by the absence of ventral tibial macrosetae and the progressive reduction of the notal and urotergal macrosetae, sharing these features with Stygiocampa, and the presence of dorsal femoral macrosetae as its differential feature (Bareth \& Condé 1984). With this definition, another troglobitic species, Plusiocampa (Plusiocampa) dargilani (Moniez, 1984) could be included in Venetocampa. Plusiocampa dargilani was found in many caves in the Central Massif, southern France (Condé 1997), and in addition, it shares with most of the species of Stygiocampa an increase in macrosetae on the urosternites.

Finally, the new subgenus Pentachaetocampa subgen. nov. bears two synapomorphic features that separate it from other already-known Plusiocampinae: the five dorsal macrosetae on the meso- and metathoracic femur and the presence of a narrow field of $g_{l}$-glandular setae on the first urosternite in adult females. No other species of Plusiocampa has five dorsal femoral macrosetae, although this does occur in another genus of Plusiocampinae. This is the case for Hystrichocampa Condé, 1948, a monospecific genus with a widely distributed species, $H$. pelletieri Condé, 1948, from several caves and mines from karst regions around the French and Swiss Jura (Condé 1948, 1962). Nevertheless, many solid features differentiate Hystrichocampa from Pentachaetocampa subgen. nov. Among them the most noticeable are: the shape and pubescence of the telotarsal processes, the absence of $g_{1}$ - glandular setae in females and the unequal claws in Hystrichocampa. Furthermore, no other Plusiocampa or Plusicampinae females bear $g_{l}$-glandular setae on the first urosternite.

Plusiocampa (Pentachaetocampa) inopinata subgen. et sp. nov. urn:1sid:zoobank.org:act:C6C66264-5935-49C3-83EF-B42D9C015314

Figs 1-17, Table 1

\section{Etymology}

Unopinatus, inopinata, inopinatum, a Latin adjective meaning unexpected or surprising, which describes how we felt after the discovery of this remarkable troglobitic new taxon in German caves.

\section{Type material}

\section{Holotype}

GERMANY: + , Schallsinger Höhle, Malsburg-Marzell, Baden-Württemberg, 11 May 2014, Dominik Fröhlich and M. Sieber leg. (ZMUC).

\section{Paratypes}

GERMANY: 4 우, 2 $\widehat{\jmath}$, from the type locality, 11 May 2014, Dominik Fröhlich leg. (ZMUC); 1 ठ, 8 Jun. 2013, Hannes Köble leg. (AS); 1 ð̃, 11 Jun. 2016, Dominik Fröhlich, Tobias Helling and Dieter Weber leg. (MNCB); 3 juvs, 11 Jun. 2016, Dominik Fröhlich, Tobias Helling and Dieter Weber leg. (AS); 1 q, 1 juv., 11 Jun. 2016, Dominik Fröhlich, Tobias Helling and Dieter Weber leg. (AS); 1 spec. and 1 juv., 11 Jun. 2016, Dominik Fröhlich, Tobias Helling and Dieter Weber leg., mounted in Marc André solution (AS).

\section{Other material examined}

GERMANY: 2 우, Schallsinger Höhle, Malsburg-Marzell, Baden-Württemberg, Germany, 11 June 2016, Dominik Fröhlich, Tobias Helling and Dieter Weber leg. (AS). 

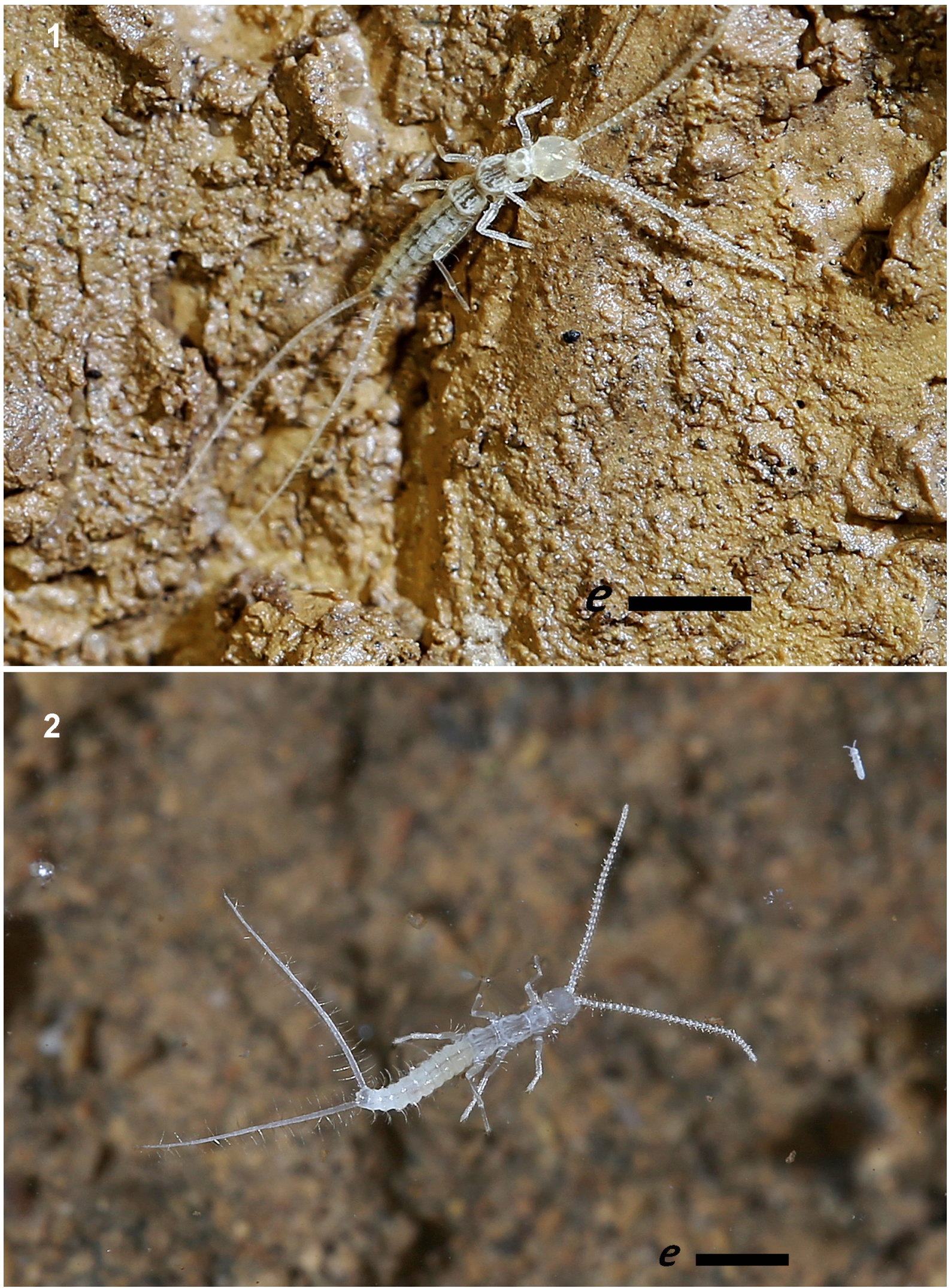

Figs 1-2. Plusiocampa (Pentachaetocampa) inopinata subgen. et sp. nov. 1. On a clay surface. 2. On the surface of a puddle from Schallsinger Höhle. Courtesy of Mirjam Widmer. Scale bars $=2 \mathrm{~mm}$. 


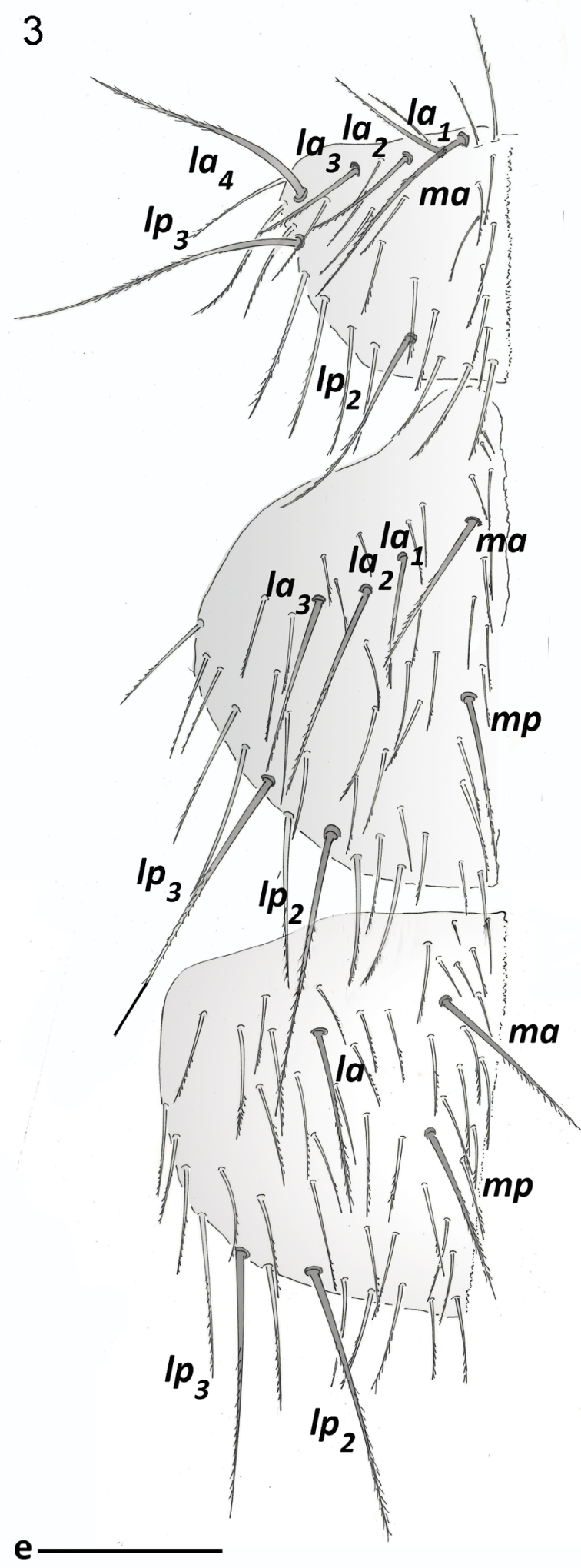

4

II
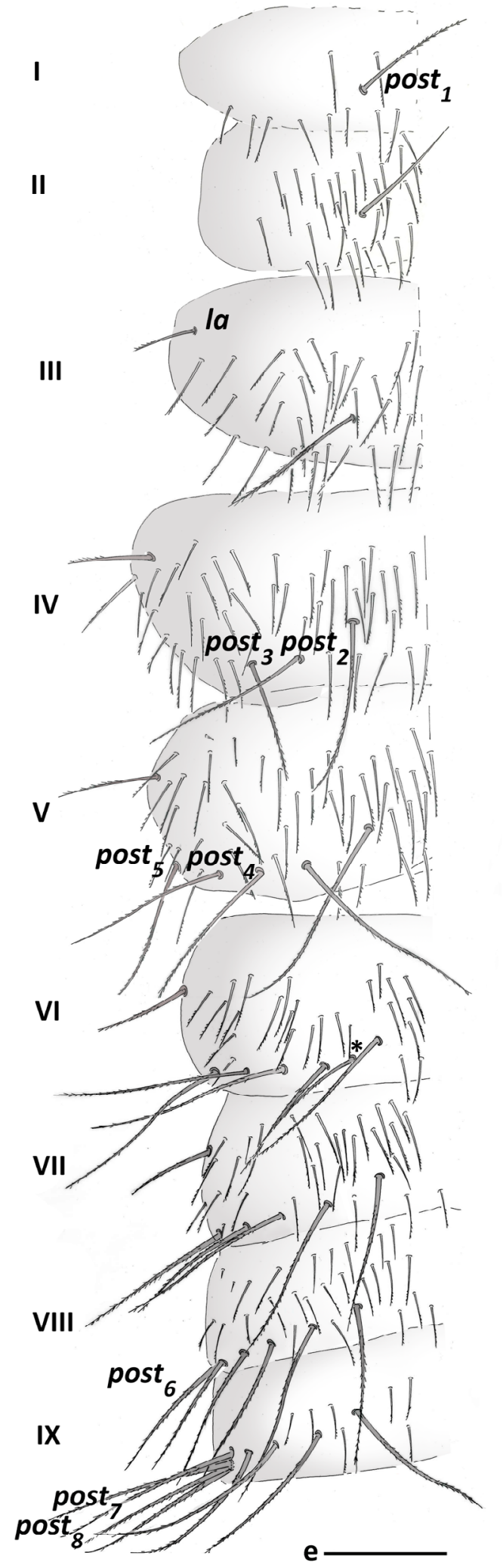

Figs 3-4. Plusiocampa (Pentachaetocampa) inopinata subgen. et sp. nov., holotype, $\uparrow$. 3. Pro-, mesoand metanotum, left side. 4. Urotergites I-IX, left side. Scale bars $=0.2 \mathrm{~mm}$. 

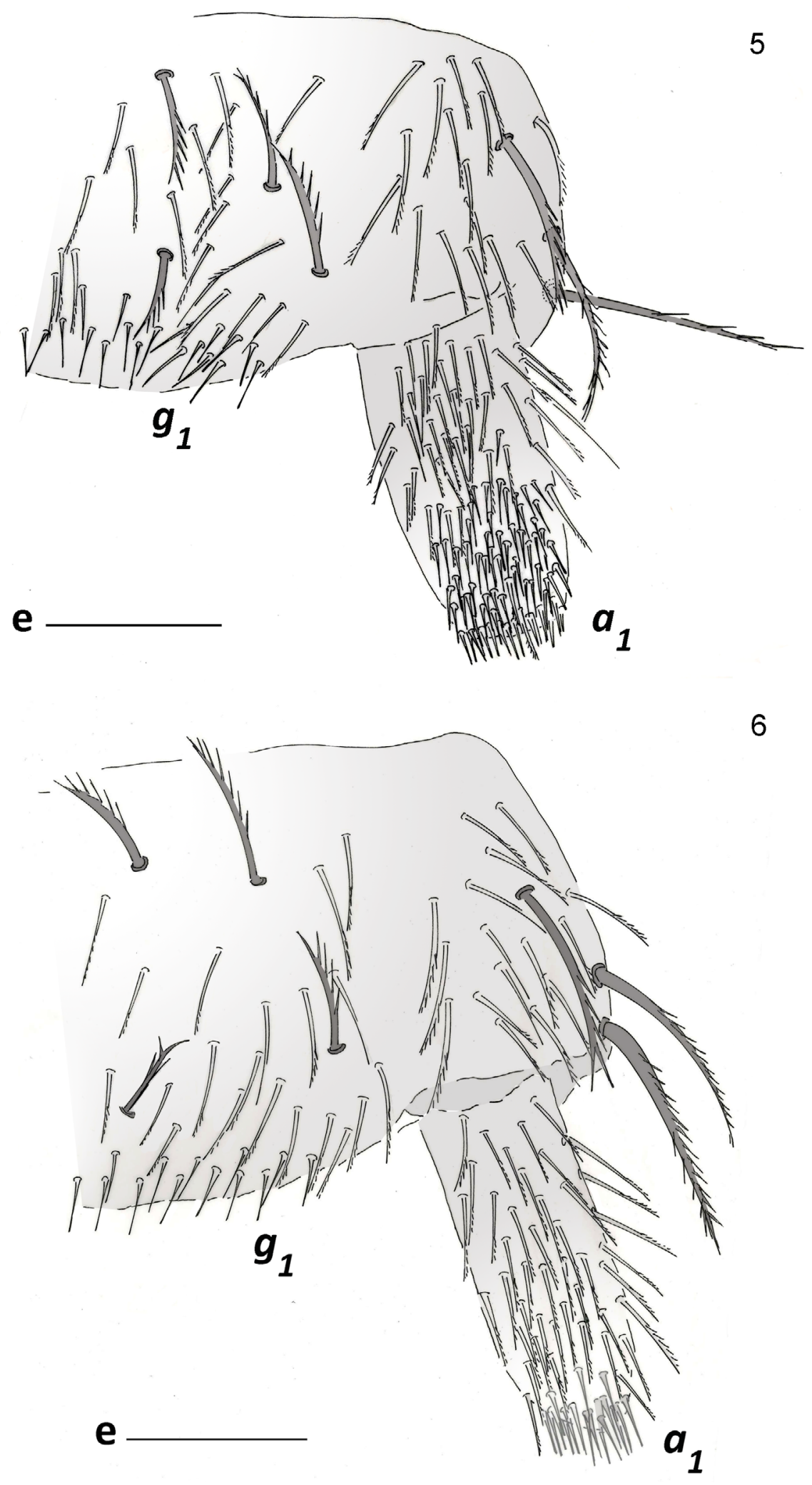

Figs 5-6. Plusiocampa (Pentachaetocampa) inopinata subgen. et sp. nov. Urosternite I. 5. Male. 6. Female. $a_{1}=a_{1}$-glandular setae, $g_{1}=g_{1}$-glandular setae. Scale bars: $=0.1 \mathrm{~mm}$. 


\section{Description}

MEasurements. Body length 3.1-5.5 mm (males), 3.9-5.4 mm (females) and 2.2-2.3 mm (juveniles) (Figs 1-2; see Supplementary File 2). Epicuticle smooth under optical microscope but slightly reticulated in high magnifications; body with sparse thin and long clothing, covered with thin barbs along the distal one third to one half (Figs 7-8).
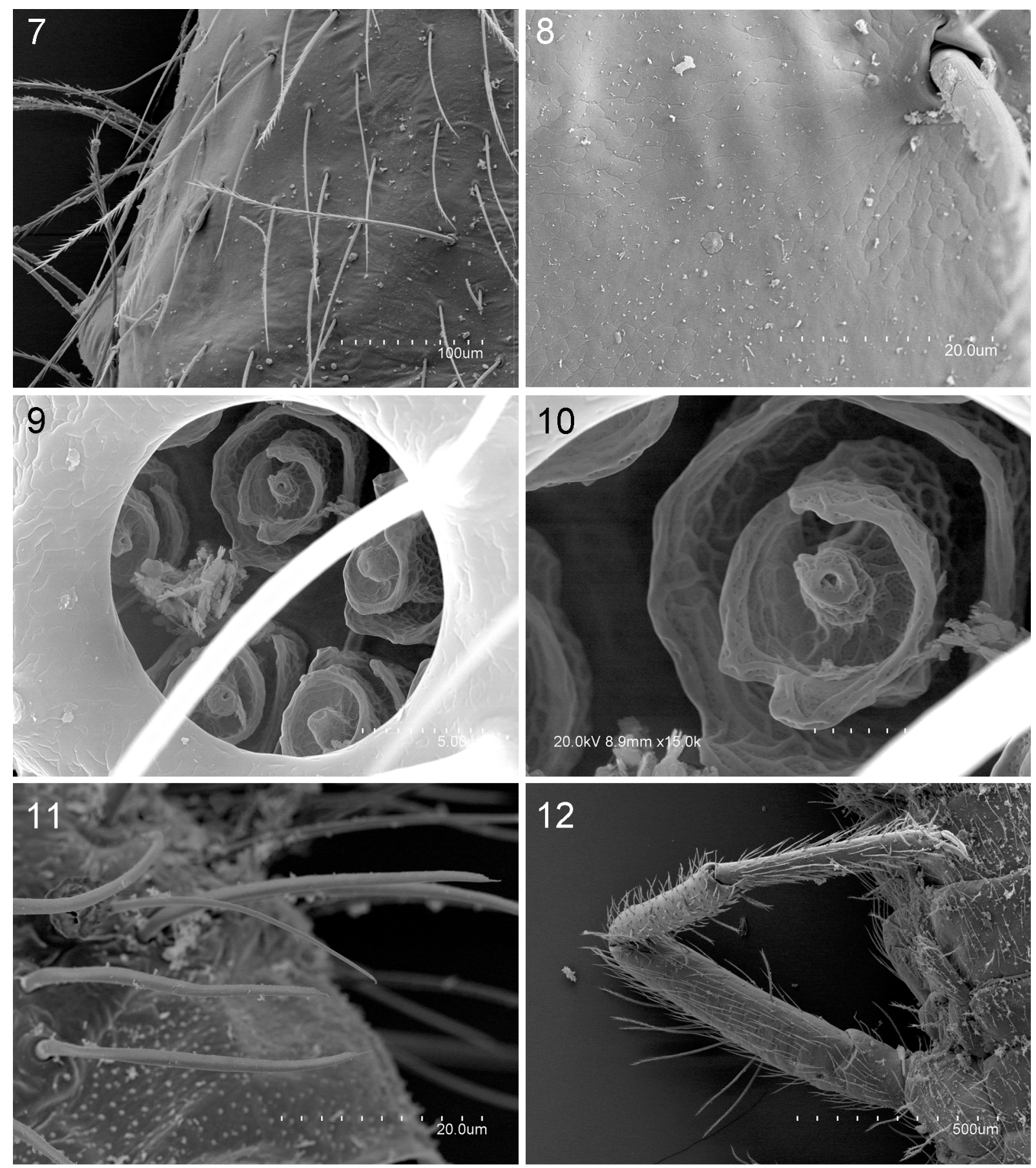

Figs 7-12. Plusiocampa (Pentachaetocampa) inopinata subgen. et sp. nov. 7-8. Metanotum. 7. Macrosetae $l a_{1,2,3}$ and $m p$. 8. Detail of surface. 9. Cupuliform organ of last antennomere. 10. Sensillum of cupuliform organ. 11. Gouge sensilla. 12. Metathoracic leg. Scale bars in $\mu \mathrm{m}$. 
HEAD. Two intact antennae in adults with 32 and 33 antennomeres and three in juveniles with 32, 32 and 33 antennomeres. Small sensillum of third antennomere located in ventral position between $d$ and $e$ macrosetae. Central antennomeres 1.5 times as long as wide in adults and juveniles, 2.0 times in the apical antennomere. Large cupuliform organ occupying $1 / 6$ of total length of apical antennomere with $12-14$ olfactory chemoreceptors with $2-3$ collaretes, each one covered completely by small pores
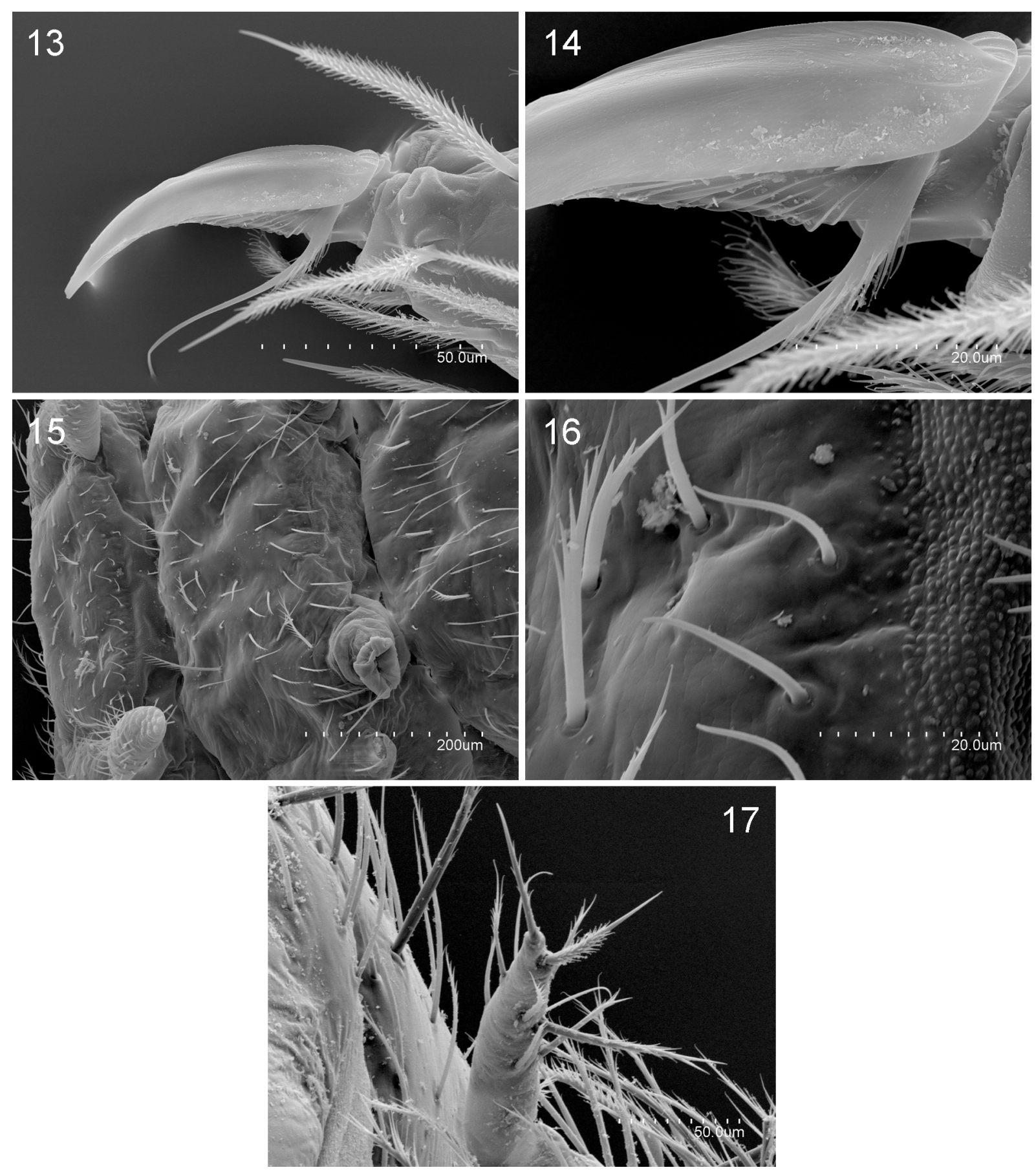

Figs 13-17. Plusiocampa (Pentachaetocampa) inopinata subgen. et sp. nov. 13. Tarsal end of metathoracic leg. 14. Detail of telotarsal claw. 15. Urosternites I-II of a female. 16. $g_{l}$-glandular setae of urosternite I of a female. 17. Stylus of urosternite VII. Scale bars in $\mu \mathrm{m}$. 
Table 1. Plusiocampa (Pentachaetocampa) inopinata subgen. et sp. nov., length of the body, antennomeres, metathoracic leg and cerci (units in $\mathrm{mm}$ ), and number of antennomeres and cercal articles.

\begin{tabular}{|c|c|c|c|c|c|c|}
\hline \multirow[b]{2}{*}{ Specimen } & \multicolumn{4}{|c|}{ Antennae } & \multicolumn{2}{|c|}{ Cerci } \\
\hline & $\begin{array}{l}\text { Body } \\
\text { length }\end{array}$ & Antennomeres & Length & $\begin{array}{c}\text { Length } \\
\text { metathoracic } \\
\text { leg }\end{array}$ & $\begin{array}{c}\text { Articles, } \\
\text { basal } \\
\text { included }\end{array}$ & Length \\
\hline Paratype, juvenile (AS) & 2.3 & 32 & 2.0 & 1.3 & 7 & 2.0 \\
\hline Paratype, juvenile (AS) & 2.5 & 32 & 2.2 & 1.4 & - & - \\
\hline Paratype, juvenile (AS) & 2.6 & 33 & 2.2 & 1.3 & - & - \\
\hline Paratype, $\widehat{\partial}(\mathrm{MNCB})$ & 3.2 & - & - & 1.8 & - & - \\
\hline Paratype, $q$ (ZMUC) & 3.9 & 33 & 2.8 & 2.0 & - & - \\
\hline 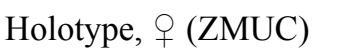 & 4.1 & - & - & 2.3 & - & - \\
\hline Paratype, + (ZMUC) & 4.2 & - & - & 2.4 & 8 & 4.2 \\
\hline Paratype, q (ZMUC) & 4.5 & - & - & 2.5 & - & - \\
\hline Paratype, $\lesssim$ (ZMUC) & 4.6 & 32 & 3.3 & 2.4 & - & - \\
\hline Paratype, $\lesssim$ (ZMUC) & 4.6 & - & - & - & - & - \\
\hline Paratype, $q$ (ZMUC) & 5.1 & - & - & 2.5 & - & - \\
\hline Paratype, + (AS) & 5.4 & - & - & 2.7 & - & - \\
\hline Paratype, $\widehat{\partial}$ (AS) & 5.5 & - & - & 2.6 & - & - \\
\hline
\end{tabular}

(Figs 9-10). Thin and long gouge sensilla (Fig. 11) 30-35 $\mu \mathrm{m}$ long in a single distal whorl of 12-15 sensilla on each medial and distal antennomere. Frontal process developed with slightly tuberculate setae and macrosetae with thin barbs. The three macrosetae along the line of insertion of antennomere and $x$ setae with thin barbs along distal one third. Suboval labial palps with latero-external sensillum similar to sensillum of third antennomere, with two guard setae, up to 8 setae on anterior border and up to 120 neuroglandular setae.

THORACIC CHAETOTAXY. Thoracic macrosetae distribution (Fig. 3): pronotum with $1+1 \mathrm{ma}, 4+4 \mathrm{la}_{1,2,3,4}, 2+2$ $l p_{2,3}$; mesonotum with $1+1 \mathrm{ma}, 3+3 l a_{1,2,3}, 2+2 l p_{2,3}, 1+1 \mathrm{mp}$; metanotum with $1+1 \mathrm{ma}, 1+1 \mathrm{la}, \mathrm{l}, 2+2$ $l_{2,3}, 1+1 \mathrm{mp}$ macrosetae. All macrosetae long, thin, covered by very thin barbs along distal four fifths (Fig. 7); marginal setae longer than clothing setae, covered by thin barbs along distal half to two thirds. Legs elongated, metathoracic legs reaching abdominal segment X. Femur II-III with 5 dorsal macrosetae (6 on femur III of two adults) (Fig. 12); femur I with 3 dorsal macrosetae. Tibia with two or three ventral 
macrosetae covered by thin short barbs along distal half to four fifths (Fig. 12). Calcars well barbed from base to tip with long barbs (Fig. 12). Dorsal and lateral tarsal setae completely covered with thin barbs almost from base almost to tip (Fig. 13). Slightly unequal, elbow-like claws (posterior claw 1.05-1.15 as long as anterior one), with short extension at basal end of posterior claw; lateral crests well developed, noticeably ridged on ventral side (Figs 13-14) and almost smooth on dorsal side. Telotarsal process smooth and setiform, with several short proximal barbs (Figs 13-14).

Abdominal chaetotaxy. Distribution of abdominal macrosetae on tergites (Fig. 4): $1+1$ post $_{1}$ on III; $1+1$ post $_{1}$ and $1+1$ la on III; $2+2(3+2,3+3)$ post $_{1,2}$ and $1+1$ la on IV; $5+5$ post $_{1-5}$ and $1+1$ la on V-VII, $6+6(5+6,5+5)$ post on VIII; $8+8(8+7)$ post on IX. All post urotergal macrosetae long and covered by thin barbs along distal two thirds to four fifths; la urotergal macrosetae shorter than post macrosetae, covered by barbs along distal half; position of post ${ }_{1}$ macrosetae always a little bit anterior before marginal setae insertion. Urosternite I with $7+7(7+6)$ macrosetae; urosternites II to VII with $5+5$ macrosetae; urosternite VIII with $2+2$ macrosetae; all urosternal macrosetae covered by long barbs along distal half to four fifths. Apical setae of styli with a short tooth with $2-5$ small thin barbs in middle of setae; subapical and ventromedial setae covered with numerous thin barbs in middle portion of setae (Fig. 17). Cerci in adults with seven articles in addition to basal article, as long as body length; their articles show whorls of long macrosetae covered by thin barbs along distal two thirds, combined with whorls of smooth thin setae shorter than macrosetae (Table 1).

FeMALE UROSTERNITE I (Figs 6, 15-16). With subcylindrical appendages thinner than male appendages, each bearing up to $20 a_{l}$-glandular setae in a distal field; and a narrow marginal field with up to $25 g_{l}$-glandular setae in larger female adults.

Male URosternite I (Fig. 5). With moderated large subcylindrical appendages, each bearing up to $70 a_{l}$-glandular setae in a large field covering almost distal half of its ventral and apical side; and a narrow marginal field with up to $35 g_{1}$-glandular setae in longer male adults.

\section{Phyletic affinities}

Plusiocampa (Pentachaetocampa) inopinata subgen. et sp. nov. is a clearly recognizable species due to the presence of five femoral macrosetae and the presence of $g_{1}$-glandular setae in females. It differs strongly from members of other subgenera in the previously mentioned characters; but without these two differential features, $P(P$.) inopinata subgen. et sp. nov. seems to be most closely related to Plusiocampa (Plusiocampa) bonadonai Condé, 1948, based on similarities in the macrosetal formula of the thorax and abdomen and in the size and shape of the telotarsus. It is also a cave-dwelling species known from several caves, also found in endogean habitats (Condé \& Poivre 1982) in the Maritime Alps, southeastern France.

\section{Plusiocampa (Plusiocampa) dobati Condé in Dobat, 1975}

Figs 18-25

\section{Material examined}

GERMANY (All Swabian Alb, Baden-Württemberg): 1 đ, Todsburger Höhle, 29 Jun. 2013, Hannes Köble leg. (AS); 1 , Todsburger Höhle, 14 Jul. 2013, Hannes Köble leg. (AS); 1 , Blautopfhöhle, 12 Oct. 2012, S. Bauer leg. (AS); 1 क, Blautopfhöhle, 12 Oct. 2012, S. Bauer leg. (AS); 1 q, Blautopfhöhle, 29 Oct. 2012, S. Bauer leg. (AS); 1 đ̃, Blautopfhöhle, 21 Sep. 2013, Hannes Köble leg. (AS); 1 juv., Blautopfhöhle, 21 Sep. 2013, Hannes Köble leg. (AS); 1 ㅇ, Blautopfhöhle, 21 Sep. 2012, S. Bauer leg. (AS); 1 q, Bärentalhöhle, 20 Mar. 2013, Petra Boldt leg. (AS); 1 O̊, 1 q, Bärentalhöhle, 13 Sep. 2013, Petra Boldt leg. (AS); 1 q, 1 juv., Bärentalhöhle, 27 Nov. 2012, Petra Boldt leg. (AS); 1 q, Bärentalhöhle, 11 May 2013, Petra Boldt leg. (AS); 1 đ̃, 1 +, Bärentalhöhle, 13 Sep. 2013, Petra 
Boldt leg. (AS); 1 ㅇ, Bärentalhöhle, 15 Feb. 2014, Hannes Köble leg. (AS); 1 ○ૈ, Bärentalhöhle, 5 Aug. 2014, Hannes Köble leg. (AS); 1 đ, 1 ㅇ, Falkensteiner Höhle, 31 Mar. 2013, Hannes Köble leg. (AS); 1 ㅇ, Falkensteiner Höhle, 25 Apr. 2013, Hannes Köble leg. (AS); 1 đ̂, Vetterhöhle, 24 Feb. 2013,

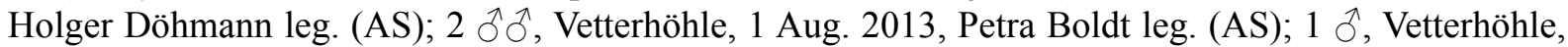
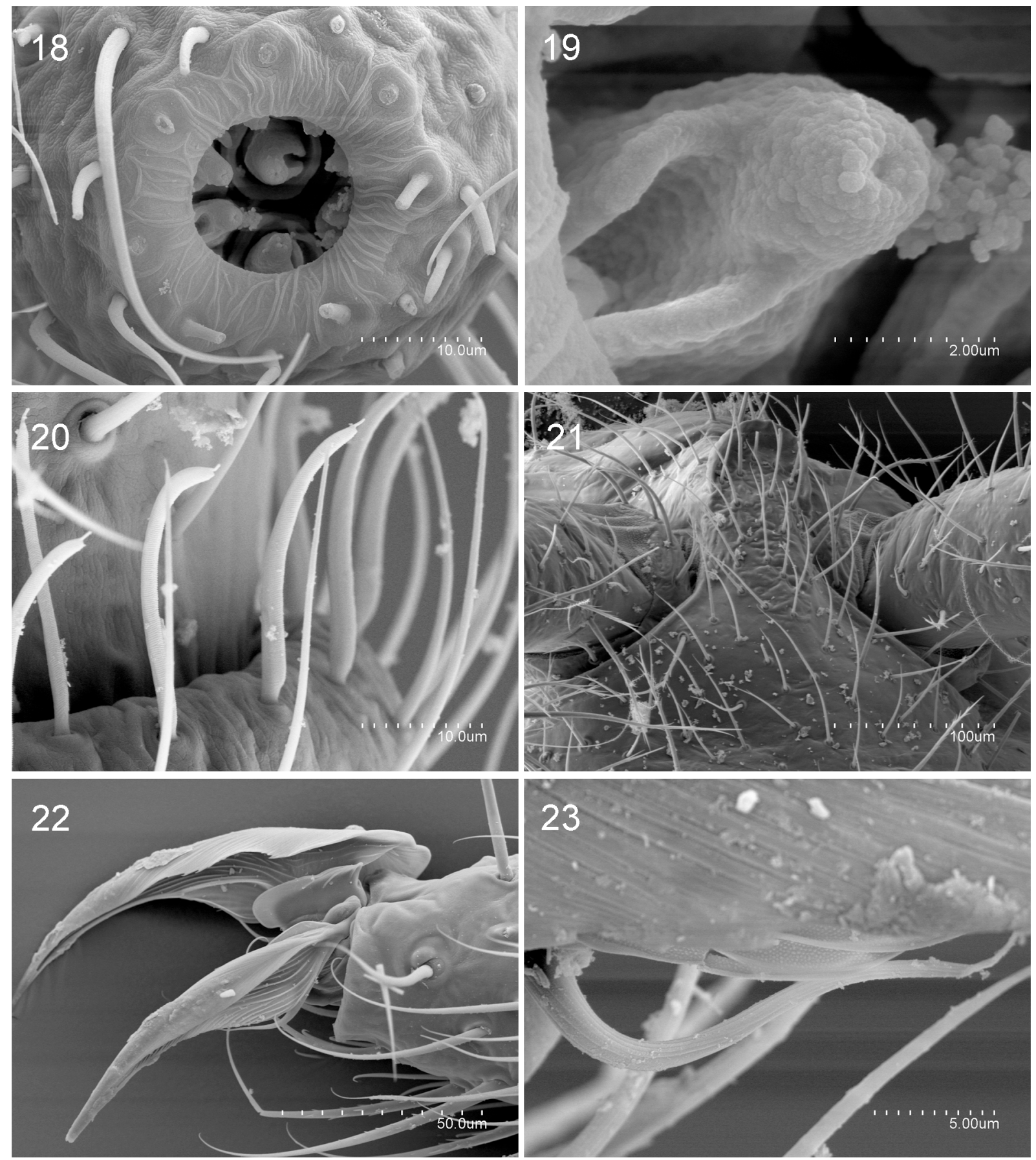

Figs 18-23. Plusiocampa (Plusiocampa) dobati Condé in Dobat, 1975. 18. Cupuliform organ of the last antennomere. 19. Central cylindrical structure of an olfatory chemoreceptor sensillum of the cupuliform organ. 20. Gouge sensilla. 21. Frontal process. 22. Telotarsal end of metathoracic leg. 23. Detail of telotarsal claw. Scale bars in $\mu \mathrm{m}$. 

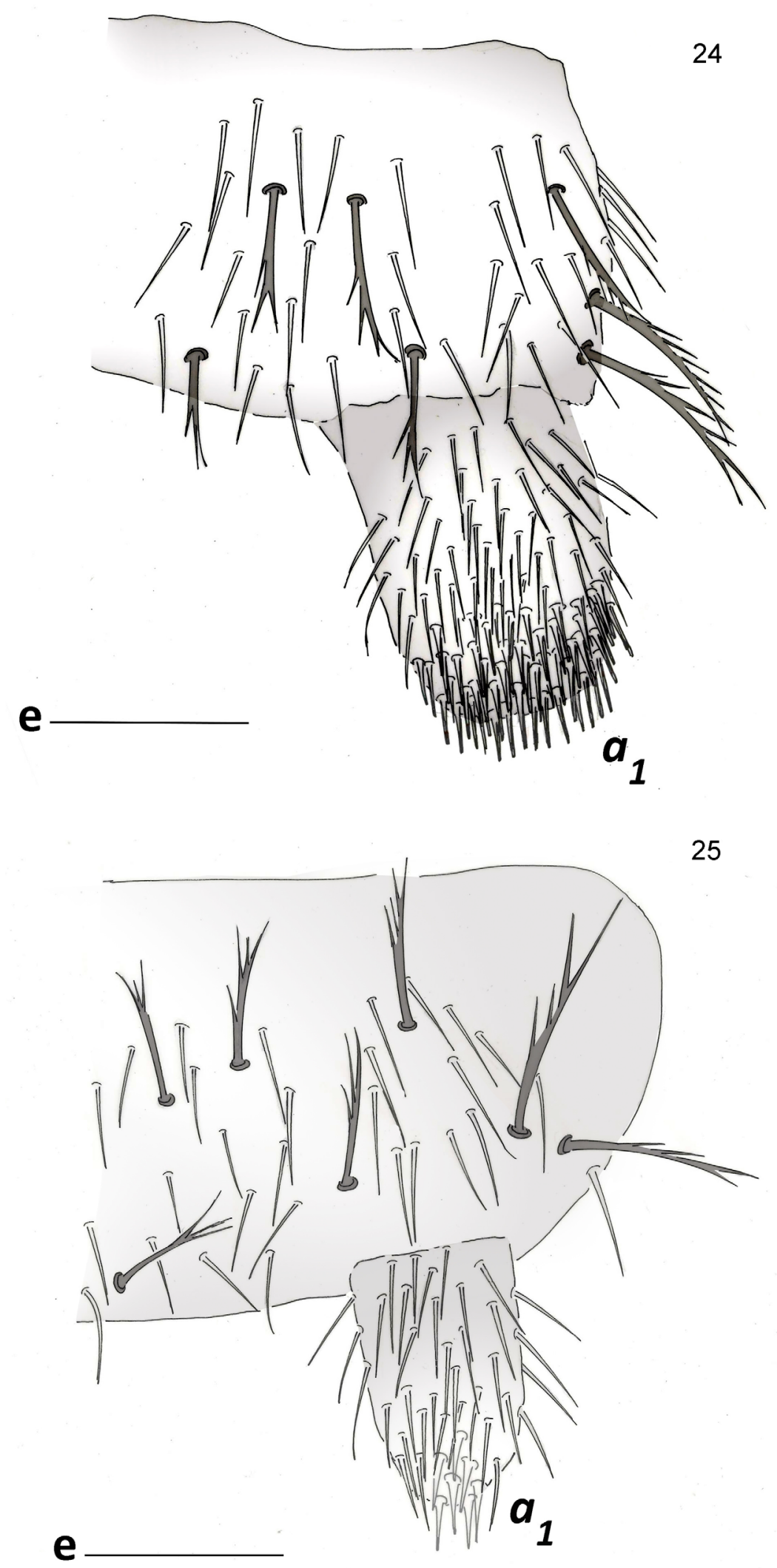

Figs 24-25. Plusiocampa (Plusiocampa) dobati Condé in Dobat, 1975. Urosternite I. 24. Male. 25. Female. $a_{1}=a_{1}$-glandular setae. Scale bars $=0.1 \mathrm{~mm}$. 
20 May 2013, Petra Boldt and Udo Wohlketzetter leg. (AS); $1 \hat{\jmath}, 1$ ㅇ, Vetterhöhle, 7 Mar. 2013, Otto Schwabe and Udo Wohlketzetter leg. (AS); 1 q, Vetterhöhle, 24 Nov. 2013, Hannes Köble leg. (AS);

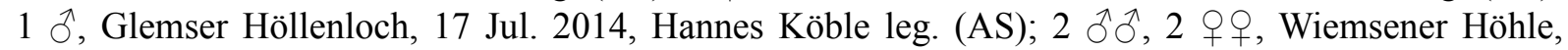
24 Mar. 2010, R. Straub leg. (AS); 1 q, Wimsener Höhle, 27 Mar. 2010, R. Straub leg. (AS); 1 juv., Hausener Bröller, 2 May 2014, Hannes Köble leg. (AS).

\section{Taxonomic remarks}

Antennae with 28 and 29 antennomeres in adults and 28 in one juvenile. Cupuliform organ with eight complex olfatory chemoreceptor sensilla characterized by a cylindrical central structure without noticeable pores, surrounded by one concentric fold (Figs 18-19). Gouge sensilla long (25 $\mu \mathrm{m})$, with a tip on the end (Fig. 20). Frontal process with a frontal and lateral rim (Fig. 21). The shortness of their telotarsal processes and the shape of the claws are confirmed (Figs 23-24). The urosternites of male and female were mentioned in the original description but no drawings were produced. In the first urosternite of both males and females there are no $g_{l}$-glandular setae and the appendages support up to $54 a_{1}$-glandular setae in males and up to nine in females (Figs 24-25).

\section{Plusiocampa (Plusiocampa) sp.}

Table 2

\section{Material studied}

GERMANY (all Franconian Alb, Bavaria): 1 juv., Geisloch near Oberfellendorf, 17 Apr. 2014, Hardy Schabdach leg. (AS); 2 우, Geisloch near Oberfellendorf, 17 Apr. 2014, Hardy Schabdach leg. (AS); 1 ठ̊, Fischerhöhle near Heuchling, 7 Jul. 2011, Hardy Schabdach leg. (AS); 1 +, Sophienhöhle near Rabenstein, 10 Jan. 2012, Hardy Schabdach leg. (AS); 1 +, Geisloch near Müzinghof, 10 May 2011, Hardy Schabdach leg. (AS).

\section{Taxonomic remarks}

Body length $2.0 \mathrm{~mm}$ in a juvenile and 3.0-3.8 mm in adults; short antennae with $20-21$ doliiform antennomeres (1-1.1 times as long as wide in middle antennomeres and 1.5 times in last one); four simple olfatory chemoreceptors in cupuliform organ; small sensillum of third antennomere in ventral position, between $d$ and $e$ macrosetae; frontal process without protrusion nor tuberculate setae; pronotum with $1+1 \mathrm{ma}, 4+4 \mathrm{la}, 2+2 \mathrm{lp}$; mesonotum with $1+1 \mathrm{ma}, 3+3 l a_{1,2,3}, 2+2 l p_{2,3}, 1+1 \mathrm{mp}$; metanotum with $1+1$ $m a, 1+1 l a, 2+2 l p_{2,3}, 1+1 \mathrm{mp}$; short legs reaching seventh abdominal segment, with two ventral tibial macrosetae; telotarsal process with small claws slightly unequal (1.1-1.2), with very short extension at basal end of posterior claw and large lateral crests; urotergites with $1+1$ post on I-II; $0-1+1$ la, $2+2$ post $_{l, 2}$ on III, $1+1$ la, $4+4$ post $_{l, 2,3,4}$ on IV, $2+2$ or $1+1$ la, $5+5$ post $_{l-5}$ on V, $2+2$ la, $5+5$ post $_{1-5}$ on VI-VII; $6+6$ post on VIII and $10+8$ to $9+9$ on abdominal segment IX; male with slightly enlarged appendages, having $a_{1}$-glandular setae in addition to a field of $g_{1}$-glandular setae; female appendages slightly thin, having $a_{1}$-glandular setae; cerci approximately half of body length with 6-7 articles plus base.

\section{Phyletic affinities}

This small Plusiocampa s. str. sp. from Franconian Alb caves is characterized by its short appendages, modest claws, low number of antennomeres and cercal articles in addition to only four olfactory chemoreceptors in the cupuliform organ; all of these non-troglomorphic features indicate a not exclusively subterranean life for this species. Due to this, Plusiocampa s. str. sp. can be considered a troglophile form that can live in subterranean superficial habitats or humid soils. This troglophile life-style can be seen in other Plusiocampa species described from Hungarian caves (Stach 1929; Loksa 1960). This is the case for Plusiocampa (Plusiocampa) spelaeae Stach, 1929 from Baradla Cave (Gömör, northern Hungary) and Plusiocampa (Plusiocampa) breviantennata Loksa, 1960 from Lócz Cave (Balatonfüred, 
Table 2. Plusiocampa (Plusiocampa) sp. from Franconian Alb caves, length of the body, antennomeres, metathoracic leg and cerci (units in $\mathrm{mm}$ ), and number of antennomeres and cercal articles.

\begin{tabular}{|c|c|c|c|c|c|c|}
\hline \multirow[t]{2}{*}{ Sex } & \multirow{2}{*}{$\begin{array}{l}\text { Body } \\
\text { length }\end{array}$} & \multicolumn{2}{|c|}{ Antennae } & \multirow{2}{*}{$\begin{array}{c}\text { Metathoracic } \\
\text { leg length }\end{array}$} & \multicolumn{2}{|c|}{ Cerci } \\
\hline & & Antennomeres & Length & & Articles & Length \\
\hline Juvenile (AS) & 2.0 & - & - & - & - & - \\
\hline$\widehat{\partial}(\mathrm{AS})$ & 3.2 & 21 & - & - & - & - \\
\hline$q(\mathrm{AS})$ & 3.5 & - & - & - & - & - \\
\hline$\widehat{\partial}(\mathrm{AS})$ & 3.7 & 20 & 1.8 & 1.4 & $6+$ base & 1.6 \\
\hline$q(\mathrm{AS})$ & 3.4 & 21 & 2.1 & 1.4 & - & - \\
\hline q $(\mathrm{AS})$ & 3.8 & 21 & 1.9 & 1.4 & $7+$ base & 2.0 \\
\hline
\end{tabular}

Hungary). Nevertheless, both cave-dwelling Hungarian species were poorly described and nowadays it is impossible to make a complete comparison with other species of Plusiocampa. Furthermore, both Hungarian species apparently lack medial posterior macrosetae on the mesonotum and metanotum.

The traits related with the small size observed in this Franconian Alb Plusiocampa s. str. sp., in addition to the presence in this species of thoracic medial posterior macrosetae, are found in a soil-dwelling species, Plusiocampa (Plusiocampa) humicola Ionescu, 1951, recently redescribed by Sendra et al. (2012). However, in the males of $P$. (P.) humicola $g_{1}$-glandular setae are absent and that species was also found far from Germany in Cluj (Romania).

It is also possible to look into the affinities of Plusiocampa s. str. sp. from Franconian caves in a species of Plusiocampa from a less distant area. The latter was informally referred to as Plusiocampa strohuali cavicola Vornatscher, 1943 and it has been reported from several Austrian caves (Condé 1954). Nevertheless, further sampling of material from the type location is the only solution to unravelling the taxonomic mess of several Plusiocampa species from Central Europe.

\section{Discussion}

\section{Current knowledge of subterranean Campodeidae fauna in Central Europe}

The distribution of the subterranean campodeids around the European Mediterranean region has its northern limits from Belgium to the Crimea Peninsula, going along the southern limit of the Pleistocene glaciations. This lack of subterranean fauna under the glacial influence was pointed out early by Racovitza (1907) and remarked on in more recent distributional studies from Europe (Culver et al. 2006, for instance). The reason for this absence of subterranean fauna was also remarked on by Racovitza (1907), citing the lack of food in the form of organic material that could not reach the caves through the network of voids in the vadose zone (Sendra \& Reboleira 2014; Jiménez-Valverde et al. 2017).

In the case of Plusiocampa and Hystrichocampa, both included in the subfamily Plusiocampinae (Paclt 1957), the northern limits, always below the 50th parallel north, are occupied by four nontroglomorphic species of Plusiocampa (Fig. 26; see Supplementary File 1), all species with short antennae 
with doliform antennomeres plus four simple cupuliform sensilla, and also a small body with short legs and cerci. Four non-troglobitic species are distributed from west to east: $P$. (P.) humicola found in soil habitats in Romania (Sendra et al. 2012); P. (P.) spelaea described from two caves, one from the north of Hungary (Stach 1929) and another from the south of Slovakia (Paclt 1956); Plusiocampa (Plusiocampa) corcyraea Silvestri, 1912, another soil-dwelling species found in the Czech Republic (Paclt 1961, 1979; Rusek 1964) and Slovakia (Paclt 1965); and Plusiocampa (Plusiocampa) sp. known from the Franconian Alb caves in this study. Among these non-troglomorphic species, $P$. (P.) breviantennata, found in a single cave in the center of Hungary (Loksa 1960), can also be included (Fig. 26).

Towards the south-west of these non-troglomorphic species and surrounded by the Central Alps, in lower mountains regions and consequently less affected by glaciations, there are caves inhabited by troglobitic species of Plusiocampa and Hystrichocampa. In the Austrian Alps, caves are occupied by Plusiocampa (Plusiocampa) strouhali Silvestri, 1933 and its subspecies P. (P.) strouhali cavicola; Plusiocampa (Plusiocampa) caprai Condé, 1950, which is also known from shallow subterranean habitats, is the only species whose distribution reaches the extreme east of Switzerland (Condé 1950, 1962; Janetschek 1952; Christian et al. 1996); and the remarkable species Plusiocampa (Plusiocampa) hoelzeli (Neuherz, 1984), described from a single cave in Carinthia (Neuherz 1984). In regions north of the Alps, German caves are occupied by three species: P. (P.) dobati in the Swabian Alb, Plusiocampa (Plusiocampa) sp. from the Franconian Alb and the new P. (Pemturochaeta) inopinata subgen. et sp. nov. in a small karst area in the south of the Black Forest. Plusiocampa (P.) dobati and the new one represent the only troglobiont diplurans from Germany, not far from the northern-most troglobiont diplurans in Europe.

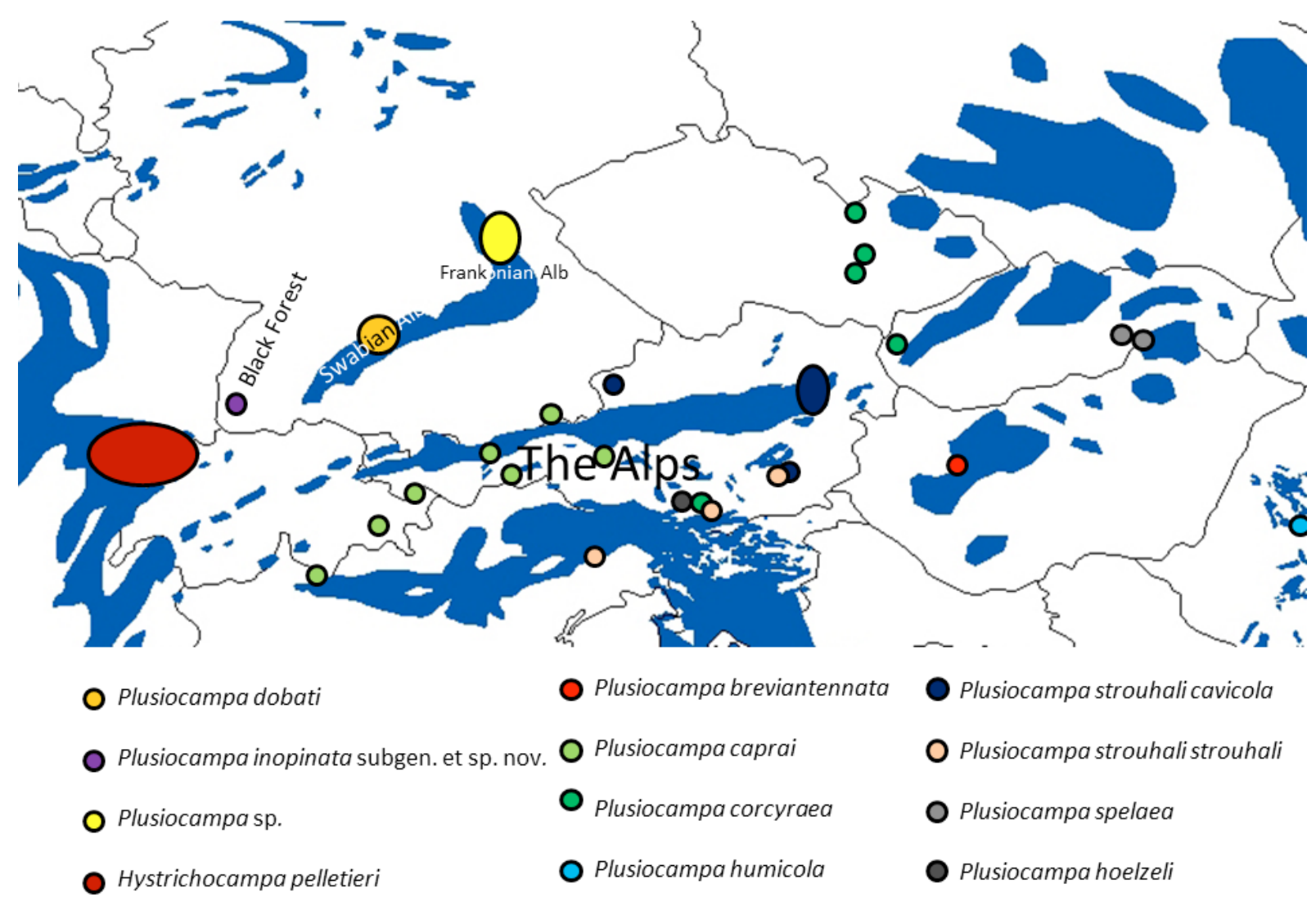

Fig. 26. Distribution of Plusiocampinae (Plusiocampa Silvestri, 1912 and Hystrichocampa Condé, 1962) in Central Europe; blue indicates karst regions. 
And finally, in caves of the Western Central Alps the relict species Hystrichocampa pelletieri Condé, 1962 can be found (Fig. 26).

The current phylogeny and the palaeobiogeographical data known for species of Plusicampinae suggest that the colonization of Europe ocurred during the first half of the Cenozoic, probably from Asia (Sendra et al. 2004). The Plusiocampinae settled in Central Europe and suffered continuous climatic changes, mainly during the Pleistocene, that could have wiped out different Pluiocampinae species several times. This glaciation frontier is nowadays occupied by four non-troglobitic species of Plusiocampa s. str. living in subterranean and edaphic habitats. However, only slightly towards the south troglobitic Plusiocampa s. str. species appear. Surprisingly, two species from different genera appear, both considered as relict due to their northeastern distribution in Europe and their unique features: the unexpected $P$. (Pentachaetocampa) inopinata subgen. et sp. nov. and H. pelletieri, both troglobites inhabiting the north-east of the Central Alps.

\section{Acknowledgements}

Firstly, we would to bring up the vital sampling efforts made by Petra Boldt, Otto Schwabe, Udo Wohlketzetter, Holger Döhmann, Dominik Fröhlich, S. Bauer, M. Sieber, R. Straub, Hannes Köble, Hardy Schabdach and Tobias Helling. We thank Mirjam Widmer for taking photos of P. inopinata alive in the cave, Hannes Köble for taking the video and Christian Zaenker for optimizing it. We are really grateful for their support. Secondly, AS would like to express his deepest gratitude to Miguel Ángel Alonso Zarazaga for his help in etymology, now and during recent years; also to his English teacher Katie Marsen for many years helping with the revision of manuscripts. We are also indebted to the electronic microscope facility at the Universitat de València, especially to Enrique Navarro and Pilar Gómez. And finally, thanks to Monica Gallart who with her expertise in Photoshop helped us in the final process of preparing the drawings.

\section{References}

Bareth C. \& Condé B. 1981. Nouveaux campodéidés de grottes d'Espagne. Revue suisse de Zoologie 88 (3): 775-786. https://doi.org/10.5962/bhl.part.82407

Bareth C. \& Condé B. 1984. Nouveaux Plusiocampa cavernicoles d'Italie continentale (Diplura Campodeidae). Bollettino della Società entomologica italiana 116 (8-10): 132-147.

Christian E., Graf W. \& Moog O. 1996. Plusiocampa caprai - Ein "Höhlentier" in den Kärntner Zentralalpen. Carinthia II 186/106: 387-392.

Condé B. 1948. Les campodéidés cavernicoles du Jura. Bulletin de l'Association spéléologique de l'Est 1 (1): $1-6$.

Condé B. 1950. Description d'un campodéidé cavernicole de Lombardie. Doriana (Annali del Museo Civico di Storia Naturale "G. Doria”) 1 (3): 1-4.

Condé B. 1954. Ordnung: Entotropha (Diplura). In: H. Franz (ed.) Die Nordost-Alpen im Spiegel ihrer Landtierwelt: 644-649. Universitätsverlag Warner, Innsbruck.

Condé B. 1956. Matériaux pour une monographie des diploures campodéidés. Mémoires du Muséum national d'Histoire naturelle, Série A, Zoologie 12: 1-202.

Condé B. 1962. Géonémie des diploures troglobies du Jura et du Vercors. Spelunca Mémoires 2: 119127.

Condé B. 1993. Une lignée danubienne du genre Plusiocampa (Diploures Campodéidés). Revue suisse de Zoologie 100 (3): 735-745. https://doi.org/10.5962/bhl.part.79881 
Condé B. 1996. Diploures campodéidés de la Pestera de la Movile (Movile Cave), Dobroudja méridionale (Roumanie). Revue suisse de Zoologie 103 (1): 101-114.

https://doi.org/10.5962/bhl.part.79940

Condé B. 1997. Campodéidés des grottes du Parc Naturel Régional des Grands Caussess (Insecta, Diplura). Mémoires de Biospéologie 24: 157-162

Condé B. \& Bareth C. 1996. Une évaluation de Stygiocampa, sous-genre troglomorphe du Plusiocampa (Diplura Campodeidae), avec la description d'une nouvelle espèce de Serbie orientale. Revue suisse de Zoologie 103 (2): 369-381.

Condé B. \& Poivre C. 1982. Plusiocampa bonadonai Condé au Valais (Insecta, Diplura). Revue suisse de Zoologie 89 (1): 167-176.

Culver D.C., Deharveng L., Bedos A., Lewis J.J., Madden M., Reddell J.R., Sket B., Trontlj P. \& White D. 2006. The mid-latitude biodiversity ridge in terrestrial cave fauna. Ecography 29: 120-128.

https://doi.org/10.1111/j.2005.0906-7590.04435.x

Dobat K. 1975. Die Höhlefauna der Schwäbischen Alb mit Einschluß des Dinkelberges, Schwarzwaldes und des Wutachgebietes. Jahreshefte des Vereins für vaterländische Naturkunde in Württemberg 130: 260-381.

Janetschek H. 1952. Beitrag zur Kenntnis der Höhlentierwelt der Nördlichen Kalkalpen. Jahrbuch des Vereins zum Schutz der Alpenpflanzen und -Tiere 1952: 3-27.

Jiménez-Valverde A., Sendra A., Garay P. \& Reboleira A.S.P.S. 2017. Energy and speleogenesis: Key determinants of terrestrial species richness in caves. Ecology and Evolution 2017: 1-9.

https://doi.org/10.1002/ece3.3558

Joseph G. 1882. Systematisches Verzeichniss der in den Tropfstein-Grotten von Krain einheimischen Arthropoden nebst Diagnosen der vom Verfasser entdeckten und bisher noch nicht beschriebenen Arten. Berliner entomologische Zeitschrift 26: 24-31.

Loksa I. 1960. Faunistisch-systematische und ökologische Untersuchungen in der Lóczy-Höhle bei Balatonfüred (Biospeologica Hungarica XL). Annales Universitatis Scientiarum Budapestinensis, Sectio Biologica 3: 253-266.

Neuherz H. 1984. Torocampa hölzeli n. gen., n. spec. - eine klasobionte Campodeide (Diplura, Apterygota) aus der Hafnerhöhle in den Karawanken, Kärnten. Carinthia II 174/94: 415-427.

Paclt J. 1956. Diplura Slovenska a pril'ahlých oblastí. Biologické práce SAV 2 (6): 5-25.

Paclt J. 1957. Diplura. Genera Insectorum 212. P. Wytsman, Brussels.

Paclt J. 1961. Campodeidae des Senckenberg-Museums (Ins.-Diplura). Senckenbergiana biologica 42 (5/6): 455-458.

Paclt J. 1965. Neue Beiträge zur Kenntnis der Apterygoten-Sammlung des Zoologischen Staatsinstituts und Zoologischen Museums Hamburg. I. Diplura. Entomologische Mitteilungen aus dem Zoologischen Staatsinstitut und Zoologischen Museum Hamburg 3 (54): 93-104.

Paclt J. 1979. Neue Beiträge zur Kenntnis der Apterygoten-Sammlung des Zoologischen Instituts und Zoologischen Museums der Universität Hamburg: VI. Weitere Doppel- und Borstenschwänze (Diplura: Campodeidae; Thysanura: Lepismatidae und Nicoletidae). Entomologische Mitteilungen aus dem Zoologischen Museum Hamburg 6 (105): 221-228.

Racovitza E.G. 1907. Essai sur les problèmes biospéologiques. Archives de Zoologie expérimentale et générale 6: 371-488. 
Rusek J. 1964. Über die Diplura (Apterygota) der Tschechoslowakei. Acta Societatis Zoologicae Bohemoslovacae 28: 134-154.

Sendra A. \& Reboleira A.S.P.S. 2014. La extensión y los límites de la fauna en los hábitats subterráneos. Boletín de la Asociación española de Entomología 38: 203-224.

Sendra A., Lara M.D., Ruiz Avilés F. \& Tinaut A. 2004. Une nouvelle espèce du genre Plusiocampa Silvestri, 1912 (Diplura, Campodeidae) et données pour sa reconstruction paléobiogéographie dans les Bétiques. Subterranean Biology 2: 113-122.

Sendra A., Nitzu E. \& Sanjuan A. 2012. Half a century after Ionescu's work on Romanian Diplura - A faunal contribution based on material collected from karst areas. Travaux de l'Institut de Spéologie "Émile Racovitza" 51: 37-66.

Sendra A. Sket B. \& Stoev P. 2017. A striking new genus and species of troglobitic Campodeidae (Diplura) from Central Asia. Subterranean Biology 23: 47-68. https://doi.org/10.3897/subtbiol.23.14631

Silvestri F. 1949. Descrizione di due specie nuove cavernícole di Campodeidae (Insecta Diplura) della regione del Monte Tauro. Bolletino del Laboratorio d'Entomologia agraria in Portici 9: 27-31.

Stach J. 1929. Verzeichnis der Apterygogenea Ungarns. Annales Musei Nationalis Hungarici 26: 269274.

Manuscript received: 9 November 2017

Manuscript accepted: 5 February 2018

Published on: 25 April 2018

Topic editor: Gavin Broad

Desk editor: Pepe Fernández

Printed versions of all papers are also deposited in the libraries of the institutes that are members of the EJT consortium: Muséum national d'Histoire naturelle, Paris, France; Botanic Garden Meise, Belgium; Royal Museum for Central Africa, Tervuren, Belgium; Natural History Museum, London, United Kingdom; Royal Belgian Institute of Natural Sciences, Brussels, Belgium; Natural History Museum of Denmark, Copenhagen, Denmark; Naturalis Biodiversity Center, Leiden, the Netherlands; Museo Nacional de Ciencias Naturales-CSIC, Madrid, Spain; Real Jardín Botánico de Madrid CSIC, Spain. 


\section{Electronic supplementary material}

Supplementary File 1

Table localities of Plusiocampinae from Central Europe.

Supplementary File 2

Video of Plusiocampa (Pentachaetocampa) inopinata subgen. et sp. nov. from Schallsinger Höhle, Malsburg-Marzell, Baden-Württemberg; courtesy of Hannes Köble. 